\title{
Personality Traits as Predictors of Authentic Leadership
}

\author{
A.Komariah \\ Universitas Pendidikan Indonesia \\ Bandung, Indonesia \\ aan_komariah@upi.edu
}

\begin{abstract}
- the purpose of this study was to investigate the predictability of traits personality towards authentic leadership madrasah principal and also to examine the relation of five factors of personality with dimensions of their authentic leadership. Participants for this study consisted of madrasah principal of madrasah aliyah at Tasikmalaya Regency. This study found that traits-personality made significant contributions to authentic leadership. Moreover, it was determined that two of five factors of personality, conscientiousness and openness to experience were predictors for authentic leadership dimensions of madrasah principal.
\end{abstract}

Keywords: Authentic Leadership, Traits-Personality, Madrasah Principal

\section{INTRODUCTION}

The assumption that Islamic education institution cannot compete with the others which caused by the condition most of the institution still used traditional management and only seen as an option is no more longer valid (Muhaemin, 2012).More parents are now entrusted their child education to Islamic School with the evidence shows the full-booked seats in almost all government and private Islamic school. Through Islamic institution, the society wish their kids to have the internalization of Islamic values in the daily lives and hereafter. This is sufficient to prove that Islamic institution still plays important role in the society. Government Regulation No 55 in 2007 about Religion Education contributes in giving a good chance of Islamic education development.

Some upper secondary of Islamic schools (madrasah) in Tasikmalaya are no more longer becoming the second option, hence they are the best option for both societies from regional and outside the city. The city of 'santri' (Muslim students) is becoming the city trademark and it is related with its existence and values. Some studies on Islamic School proved that its existence cannot be separated from Islamic School Leadership. The ideal concepts of Islam, like togetherness, hard work, discipline, optimism, persistence, open minded, cleanliness, are required in becoming the authentic Islamic School's leader.

An authentic leader with high self-discipline is urgently required to make his vision come true with the touch of sincerity. George (2014: 32) states that we need authentic leaders, "my hope is that you will be inspired to become an authentic leader, committed to making the world better for all its citizens, and leading with your heart as well as your head". Becoming an authentic leader for an Islamic School is a must as he is expected to work sincerely with high dedication and high spirited. He should be able to empower all the member of organization to work based on their capacity and transforming his tasks with emphatic and effective communication.

The madrasah leadership requires a leader to be authentic, a leader who must be honest to himself (May, Chan, Hodges, \& Avolio, 2003). Meaning, it is possessed the harmony between the behavior and trust. To be the authentic leader, George (2003) shows a statement, "To become authentic, each of us has to develop our own leadership style, consistent with our personality and character". That to be authentic, each of us must develop our own leadership style, according to the personality and our character. If we are not consistent with what are from ourselves, how it can be possible to be a true leader. The authentic leaders are consistent and show the unity of mindattitude-action. Developing the authentic leadership in an organization teaching the value system and in the turbulence situation is very prominent (Cooper et al, 2005). The spirituality and spiritual identity are the core of authentic leadership (Klenke, 2007).

The authentic leadership firmly stands on the personality. Personality becomes an important variable in realizing the authentic leadership behavior. The personality is an individual characteristic inherent in a person and is stable over time. The personality concept is explained by the personality theory which is a branch of psychology. This concept reflects a paradigm shift in the field of psychology such as personality characteristics and individual differences, including work behavior (McCrae \& Costa, 1992). The personality characteristics that are often used in various studies related to the one's work behavior is The Big Five Personality, which divides the personality characteristics into five dimensions, namely Openness to experience, Conscientiousness, Extraversion, Agreeableness, and Neuroticism (OCEAN).

The leaders with "O" Personality is a personality characterized by imaginative, ingenious, fondness of variety, curiosity, creativity, innovative, having a free and original thinking, and artistic characteristics; vice versa when the openness to experience characteristic is low or closed to experience, it tends to be a person who is not innovative, fondness of something routine, practical, and tending to be closed. McAdams \& Pals (2006) explain that a person with "O" personality characteristic has a high intellectual so he or she has innovation and ingenuity in solving problems. The leader with authentic behavior has a personality characteristic of openness 
to experience which has high intelligence and creativity so that he or she can carry out the effective leadership mandate.

The leaders with conscientiousness personality characteristic or " $\mathrm{C}$ " personality is the figure of hardworking, disciplined, reliable, organized, meticulous and detailed, and tending to be diligent (Rustiarini, 2013). A person with this personality characteristic has a strong motivation to achieve success (Zimmerman, 2008), and has a task-oriented behavior (Ashton \& Lee, 2007), McGregor (1954) calls this as the Y theory. Instead a careless, lazy, disorganized, and unreliable person, Mc Gregor (1954) refers it as an X human or X Theory; he or she is a leader with a low level of conscientiousness personality. Leaders with hard-working personality characteristic has great potential for the growth of authentic leadership by taking into account the authentic leadership characteristics, that is selfdiscipline.

An extraversion personality or the "E" personality characteristic highly tends to be talkative, energetic, enthusiastic, assertive and sure, friendly, and sociable (Rustiarini, 2013). Leaders with extraversion characteristic shows a tendency to spend a lot of time in social situations and expresses positive emotions (Judge et al., 2002), he or she is a jaunty and creator of the atmosphere. Meanwhile, leaders with low extraversion personality characteristic has quiet, shy, difficult to get along, and not overly excited personalities. Barrick et al. (1993) finds that this personality characteristic has a strong influence on the individual performance. Leaders with extraversion personality are someone who can potentially take into account the authenticity characteristics from the relationship. (Komariah, 2012).

Leaders with a personality characteristic of agreeableness or high "A" personality can work together in a team working, be trustworthy, caring, kind, helpful, unselfish, forgiving, and does not like to quarrel with others. In contrast, individuals with low agreeableness like find others' fault, fondness of disagreement, indifferent, disrespectful, and selfish. (Rustiarini, 2013).

Leaders with a personality characteristic of neoriticismor "N" personality is negative as indicated by such characteristics like often feeling depressed, full of tension and anxiety, easily gloomy and sad, easily agitated and depressed, and tending to have unstable emotions. Leaders should have low "N" personality with emotional stability, good ability to handle stress, not easily upset, quiet despite being in a stressful situation, and not easily stressed. (Rustiarini, 2013)

Referring to the descriptions above, the questions posed in this study is whether the leader's personality effects on the authentic leadership behavior?. Thus, this study aims to demonstrate empirically the influence of leaders' personality independently to the authentic leadership behavior. The relationship pattern between the personality variables on the authentic leadership behavior in this study is shown in Figure 1.

This study is a field study using quantitative methods, using questionnaires of a five scale-model as a means of collecting data on 77 Headmasters taken randomly. The statistical calculation for data analysis is performed by using regression analysis to determine the leader's personality to the authentic leadership behavior with SPSS.

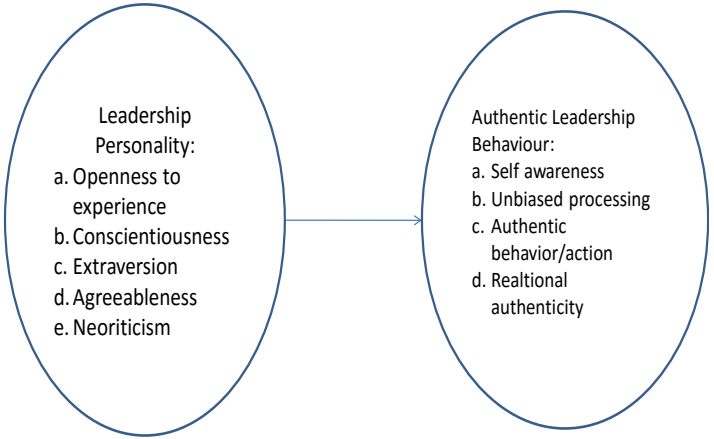

Fig. 1. The Conceptual Framework of Leaders' Personality with Authentic Leadership

The variable of the leader's personality characteristic is measured using The Big Five Personality adapted from McCrae $\&$ Costa (1992) consisting of five dimensions, namely openness, conscientiousness, extroversion, agreeableness, and neuroticism. While the authentic leadership behavior is measured based on the item model adaptation used by Walumbwa et al, (2008) and Komariah (2012) consisting of (self-awareness), unbiased processing, Authentic behavior/action, and relational authenticity.

\section{RESUlTS AND DISCUSSION}

In the descriptive analysis, it will be known the aspect distribution personality and authentic leadership variables overall which are obtained from the respondents' answers by questionnaires. The descriptive analysis results of the study variables are shown in Table 1 presenting that for the spiritual intelligence variable measurement, the highest score of the participants is the nature of thinking clearly and the lowest one is the tolerance. Meaning, generally the headmasters as the study participants in this study have the spiritual intelligence which is shown by the attitude of persevering prayer, love, honest, grateful, fair, wise in conducting duty, humble, forgiving, patient, counsellor, gentle, and a sense of responsibility. But for the tolerant attitude aspect, it needs to be improved in terms of respect the beliefs of others, open, willing to serve, not hurt, and peace

For the measurement of leader's personality characteristic, the highest score of the participants is the agreeableness and the lowest one is the neuroticism. Meaning, generally the headmasters as the participants of this study have friendly, gentle heart, trust in others, generous characteristics. The low neuroticism aspect shows that the headmasters has stable emotional, can handle stress well, are not easily upset, are quiet despite being in a stressful situation, and are not easily stressed.

For the measurement of the authentic Leadership variable, the highest score of the participants is the Self Awareness and the lowest aspect is Relational authenticity. Meaning, generally the headmasters as the participants of this study show leadership with confidence, hope, optimism, and tenacious. But for Relational authenticity aspects, it needs to be improved in terms of listening, interpreting, and processing negative and positive information objectively before making the decision. 
TABLE I. VARIABLES OF SPIRITUAL INTELLIGENCE, LEADER'S PERSONALITY CHARACTERISTICS AND AUTHENTIC LEADERSHIP OF THE MADRASAH'S HEADMASTERS

\begin{tabular}{|c|c|c|c|c|}
\hline Dimension & Average & SD & Percentage & Category \\
\hline \multirow[t]{2}{*}{ Openness } & & 0,71 & & Very \\
\hline & 4,216 & 9 & 84,31 & High \\
\hline \multirow[t]{2}{*}{ Conscientiousness } & & 0,72 & & High \\
\hline & 3,778 & 3 & 75,55 & \\
\hline \multirow[t]{2}{*}{ Extroversion } & & 0,76 & & High \\
\hline & 3,628 & 9 & 72,56 & \\
\hline \multirow[t]{2}{*}{ Agreeableness } & & 0,70 & & High \\
\hline & 3,737 & 7 & 74,75 & \\
\hline \multirow[t]{2}{*}{ Neuroticism } & & 0,73 & & \\
\hline & 1,994 & 6 & 19,89 & Low \\
\hline \multirow[b]{2}{*}{ Self Awareness } & & 0,78 & & \multirow{3}{*}{$\begin{array}{l}\text { Very high } \\
\text { High }\end{array}$} \\
\hline & 4,268 & $\begin{array}{l}2 \\
0,76\end{array}$ & 85,37 & \\
\hline Unbiased processing & 3,919 & 2 & 78,38 & \\
\hline Authentic & & 0,80 & & High \\
\hline behavior/action & 3,824 & $\begin{array}{l}5 \\
0,84\end{array}$ & 76,49 & High \\
\hline Relational authenticity & 3,729 & 4 & 74,58 & \\
\hline
\end{tabular}

The regression analysis by inputting leader's personality characteristic variables produce a regression equation of $\mathrm{Y}=$ $19.778+0,1794 \mathrm{X}$. with ei $=71.80$ and $\mathrm{R} 2=0.2820$. The hypothesis Testing based on the calculation results is known that $28 \%$ of authentic leadership is described by the leader's personality characteristic $(\mathrm{R}=0282)$. This shows a jointly relationship between variables of the leader's personality characteristic to the authentic leadership variable. A Constant of. 778 indicates that if the leader's personality $(\mathrm{X})$ values are zero, then authentic leadership has a value of 19.778. The regression equation means that every increase of 1 point or $1 \%$ of leader's personality characteristic variables will increase the authentic leadership of 01794 . To test whether the leader's personality characteristic effect on the authentic leadership variable, then the $\mathrm{t}$ test is conducted. Based on the calculation results, the values of all $p$ variables are less than 0.05 , which means the leader's personality characteristic all together and significantly effect on the authentic leadership. This implies that if the headmasters have high leader's personality characteristic, so the headmasters' authentic leadership will be better.

The research result of Personality characteristic of Madrasah Headmasters positively and significantly effects on the authentic leadership using five dimensions namely openness to experience, conscientiousness, extraversion, agreeableness, and neuroticism. The research result by Duehr (2005) states that the big five personality and transformational leadership will result in job performance, while Leung et al, 2004) shows that the effective leaders are considered to show the characteristics related to extraversion (open), conscientiousness (consciousness, meticulous, discipline ), agreeableness (friendly), extraversion, emotional stability / neuroticism, and openness to experience (Innovative and creative). That to realize the authentic leadership, the headmasters must have personality characteristics as the leaders in terms of high ownership in the four personality characteristics namely openness to experience, conscientiousness, extraversion, agreeableness, and must be low in terms of the personality characteristic of neuroticism
It is important for the headmasters to know the nature of their personality to be a self-evaluation tool for the implementation of authentic leadership. The Big Five Personality becomes reinforcement for the realization of authentic leadership by the extraversion which is expressed by the warmth, positive emotion, assertiveness, and gregariousness (friendship) of headmasters in taking decisions and the leadership attitudes. Openness to experience is a person required to become an authentic leader. The authenticity can take place and continue to run as the headmasters are open to new experiences, they are man of ideas and activity (action) expressed with full aesthetics and not lack of from the touch feeling. Zhou (2001) and Woodman (1993) state that one of the personality characteristics related to the individual's creative performance the organization is openness to experience. Be careful does not mean not brave and be a coward, Conscientiousness personality is related to the caution as the ideal person and not pragmatic, he is a fighter for the achievement (achievement striving) that does not just work and gives the minimum result as the implementation of duty, obeys to the consensus quality (dutifulness), has consistent endurance in working (self-discipline), clear consideration (Deliberation), and competence. A madrassa's leader is a person who maintains $3 \mathrm{~S}$ (smiles, greet, greeting) as a person who Agreeableness (friendly) who the depth of his heart is an altruism / trait kindness (generosity).

There is a positive and significant effect the leader's personality characteristic with the authentic leadership. Shamir and Eilam (2005) state that the development of authentic leadership is not only formed by the leader's brain, but it is measured by real action, feedback and reflection on the conducted behavior effect. The real action, feedback and reflection on the behavior effect are strongly influenced by the spirit and personality. A leader who has a spiritual intelligence is someone who has a high awareness (self-awareness) and authentic Leadership with dimension of self-awareness will give positive effect on the performance of the people they lead. This is due to the core characteristics owned by the leaders such as self-confidence, expectation, optimism, and a tenacious attitude which will affect the work of followers and then effect on the behavior to achieve high performance (Khan, 2010). The research model developed by Avolio et al, (2005) shows that the authentic leaders affect the attitudes, behavior, and performance of followers. The headmasters' behavior who shows selfawareness will impact on (a) the emergence of the followers' confidence, (b) the expectation to increase work productivity, (c) the optimism in achieving the planned objectives, and (d) persistence in carrying out the professional duties.

\section{CONCLUSION}

There is a positive effect leader's personality characteristics to the authentic leadership of madrasah aliyah's headmasters. The authentic leadership of madrasah aliyah's headmaster is affected by personality of the leader in terms of openness, conscientiousness, extroversion, agreeableness and emotional stability / neuroticism. If the leader's personality are high, so the authentic leadership of the headmasters will also get better. Thus, the headmasters of the madrasah aliyah who have leader's personality characteristic give implications on the enhancement of headmasters' authentic leadership. The authentic ability of the headmasters can be seen from the implementation of self- 
awareness, processing Unbiased, authentic behavior / action and relational authenticity which comes with full confidence, expectation, optimism, and resilient by the need to improve the ability to hear, interpret, and process negative and positive information objectively before the decision is determined.

\section{REFERENCES}

[1] Agustian, A.G. (2001). Kecerdasan Emosi Dan Spiritual: Rahasia Sukses Membangun Kecerdasan Emosi Dan Spiritual. Indonesia: Penerbit Arga

[2] Amram, Y., \& Dryer, D. C. (2008). The Integrated Spiritual Intelligence Scale (ISIS): development and preliminary validation. 116th Annual Conference of the American Psychological Association, 1-46.

[3] Ashton, M. C., \& Lee, K. (2007). Six independent factors of personality variation: A response to Saucier. European Journal of Personality, 16, 6375.

[4] Avolio, B., \& Gardner, W. (2005). Authentic leadership development: Getting to the root of positive forms of leadership. Leadership Quarterly, 16(3), 315-338

[5] Avolio, B., Gardner, W., Walumbwa, F., \& May, D. (2004). Unlocking the mask: A look at the process by which authentic leaders impact follower attitudes and behaviors. Leadership Quarterly, 15(6), 801-823.

[6] Azanza, G., Moriano, J. A., \& Molero, F. (2013). Authentic leadership and organizational culture as drivers of employees' job satisfaction. Revista de Psicología Del Trabajo Y de Las Organizaciones, 29, 45-50. http://doi.org/10.5093/tr2013a7

[7] Barrick, M.R. \& Mount, M.K. (1993). Effects of impression management and self-deception on the predictive validity of personality constructs Journal of Applied Psychology, 81, 261-272.

[8] Cooper, C, D., Scandura, T. A., \& Schriesheim, C. A. (2005). Looking forward but learning from our past: Potential challenges to developing authentic leadership theory and authentic leaders. The Leadership Quarterly, 16, 475-493.

[9] Darvish, H., \& Rezaei, F. (2011). THE IMPACT OF AUTHENTIC LEADERSHIP ON JOB SATISFACTION AND TEAM COMMITMENT. Management \& Marketing, 6, 421-436. Retrieved from

http://ezproxy.lib.ucf.edu/login?url=http://search.proquest.com/docview/ 899216837?accountid=10003 \nhttp://sfx.fcla.edu/ucf?url_ver=Z39.882004\&rft_val_fmt=info:ofi/fmt:kev:mtx:journal\&genre=article\&sid=Pro Q:ProQ:abiglobal\&atitle=THE+IMPACT+OF+AUTHENTIC+LE

[10] Duehr, Timothy A. and Jiyce E. Bono and Judge. (2000). Five Factor Model of Personality and Transformational Leadership. Journal of Applied Psychology. 85 (5). pp:751-765

[11] Emuwa, A. (2013). Authentic Leadership : Commitment to Supervisor Follower Empowerment, and Procedural Justice Climate. Emerging Leadership Journeys, 6(1), 45-65.

[12] George, B. (2014). Authentic leadership: rediscovering the secrets to creating lasting value. Journal of the American College of Radiology: JACR, 11(5), 1-241. http://doi.org/10.1016/j.jacr.2013.11.002

[13] Judge, T. A., Bono, J. E., Ilies, R., \& Gerhardt, M. (2002). Personality and leadership: A qualitative and quantitative review. Journal of Applied Psychology, 87, 765-780.

[14] Kernis, M. H. (2003). Toward a conceptualization of optimal self-esteem. Psychological Inquiry, 14, 1-26.

[15] Khan, S.N. 2010. Impact of Authentic Leaders on Organization Performance. International Journal of Business and Management, 5 (12), December 2010.
[16] Klenke, K. (2007). Authentic Leadership: A Self, Leader, and Spiritual Identity Perspective. International Journal of Leadership Studies, 3(1), 68-97.

[17] Kuczmarski, Susan Smith., Kuczmarski, Thomas D,. (1995). Value Based Leadership. New Jersey: Prentice-Hall

[18] Leung and Bozionelos, Sing Lim, Nikos Bozionelos. (2004). Five Factor Model Traits and the Prototypical Image of the Effective Leader in theb Confucion Culture. Employee Realtions, 26 (1/2), pp: 62-71

[19] Luthans, F. 2002a. The need for and meaning of positive orga- 2008 Luthans, Avey, and Patera 219 nizational behavior. Journal of Organizational Behavior, 23: 695-706

[20] Majer, Kenneth. (2008). Values-based Leadership; A revolusionary Approach to Business Succes and Personal Prosperity. California: MajerCommunications

[21] McAdams, D. P., \& Pals, J. L. (2006). A new Big Five: Fundamental principles for an integrative science of personality. American Psychologist, 61, 204-217.

[22] McCrae, R. R., \& John, O. P. (1992). An introduction to the fivefactor model and its applications. Journal of Personality, 60, 175-215

[23] Mohamed, A.A., Wisnieski, J., Askar, M., \& Syed, I. (2004). Towards a Theory of Spirituality in the Workplace. Competitiveness Review, 14(1\&2): 102-107.

[24] Nashori, H.F., \& Mucharam, R.D. 2002. Mengembangkan kreativitas dalam Perpektif Psikologi Islami. Yogyakarta: MenaraKudus Jogja.

[25] Ningky Munir, 2003, Spiritualitas dan Kinerja, Majalah Manajemen, Vol.124, Juli 2000

[26] Nggermanto, A. (2002). Quantum Quotient-Kecerdasan Kuantum Bandung: Nuansa

[27] Noble, K.D. (2001). Riding the windhorse: Spiritual intelligence and the growth of the self. Cresskill, NJ: Hampton Press, Inc.

[28] Opatokun, K. A., Hasim, C. N., \& Syed Hassan, S. S. (2013) AUTHENTIC LEADERSHIP IN HIGHER LEARNING INSTITUTION: A CASE STUDY OF INTERNATIONAL ISLAMIC UNIVERSITY MALAYSIA (IIUM). International Journal of Leadership Studies, $8(1), \quad 49-66 . \quad$ Retrieved from http://search.ebscohost.com/login.aspx ?direct=true \&db=buh \&AN=9258 2225\&login.asp?custid=uamster\&site=ehost-live

[29] Rustiarini, N. W. (2013). Pengaruh Kompleksitas Tugas , Tekanan Waktu , dan Sifat Kepribadian pada Kinerja, 17(2), 126-138. http://doi.org/10.7454/mssh.v17i2.2961

[30] Ryan, Will. (2008). Leadership with a Moral Purpose; Turning Your School Inside Out.UK: Crown House Publishing Ltd

[31] Shamir, B., \& Eilam, G. (2005). bWhat's your story?Q: A life-stories approach to authentic leadership development. The Leadership Quarterly.

[32] Shaw, Eleanor . (1999) A guide to the qualitative research process: evidence from a small firm study. International Journal, 2, 59 - 70

[33] Sugiono. 2004. Metode Penelitian Bisnis. Bandung: Alfabeta.

[34] Trott, David. (1996). Spiritual well-being of workers: An exploratory study of spirituality in the workplace. Dissertation Abstracts International, University of Texas: Austin, TX.

[35] Walumbawa, F., Avolio, B., Gardner, W., Wernsing, T., and Peterson, S 2008. Authentic Leadership: Development and Validation of a TheoryBased Measure. Management Department Faculty Publication. paper 24.Waworuntu, B. (2003). Determinan kepemimpinan, 7(2), 71-81.

[36] Woodman, R.W., Sawyer, J.E. and Griffin, R.W. (1993), Toward a theory of organizational creativity, Academy of Management Review, Vol. 18, pp.293-321.

[37] Zhou, J., \& George, J. (2001), 'When job dissatisfaction leads to creativity: Encouraging the expression of voice', Academy of Management Journal, vol. 44 no. 4, pp. 682-696 